\title{
Histopathological and biochemical alterations in Eudrilus eugeniae (Kinberg 1867) as biomarkers of exposure to monocyclic aromatic hydrocarbons in oil impacted site
}

\author{
Funmilayo V. Doherty ${ }^{1 *}$ (D) Idowu Aneyo ${ }^{1}$ and Adebayo A. Otitoloju ${ }^{2}$
}

\begin{abstract}
Background: Monocyclic aromatic hydrocarbons are toxic compounds which are major components of petroleum products. This study was aimed at identifying histopathological alterations and changes in antioxidants defense systems in Eudrilus eugeniae (earthworm) that can be used as good battery of biomarkers for early detection of pollution associated with hydrocarbons. The toxicological evaluations of benzene, toluene, xylene, and ethylbenzene (BTEX) were carried out against E. eugeniae. Earthworm samples were collected around oil impacted and control sites. The effect of BTEX was investigated on oxidative stress markers of E. eugeniae.

Results: Results showed that xylene $(1.2 \mathrm{mg} / \mathrm{kg})$ was the most toxic compound, followed by toluene $(1.3 \mathrm{mg} / \mathrm{kg})$, ethylbenzene $(1.4 \mathrm{mg} / \mathrm{kg})$, and benzene $(1.9 \mathrm{mg} / \mathrm{kg})$. The biochemical responses revealed an increase in malondialdehyde level and decrease in the level of superoxide dismutase, catalase, glutathione, and glutathione-S-transferase in E. eugeniae collected around the oil impacted area of ljegun. The results from the laboratory studies were confirmed in the field studies. Significant histopathological alterations in the whole organisms were observed in both field and laboratory studies. The pathological findings include cellular and epidermal degeneration, and presence of pigment and inclusion bodies.

Conclusion: The results reflect the biological effects of hydrocarbon pollution, thus confirming the relevance of histopathological and antioxidant enzymes as biomarkers for detection of hydrocarbon pollution during environmental monitoring programs.
\end{abstract}

Keywords: Histopathological alterations, Eudrilus eugeniae, Biomarkers, Oil spill disaster

\section{Background}

In Nigeria, imported petroleum products are stored in tank farms, many of which are in Lagos, and these products are distributed to other parts of the country through pipelines connected all over Nigeria. Nigeria has a wide pipeline network and depots for distributing refined petroleum products (Renner et al. 2008). There are about $5000 \mathrm{~km}$ of pipelines and about 20 oil depots altogether in Nigeria (Adewuyi and Olowu, 2012). Frequent petroleum

\footnotetext{
* Correspondence: funmilayodoherty@yahoo.co.uk

${ }^{1}$ Environmental Biology Unit, Department of Biological Science, Yaba College of Technology, Lagos, Nigeria

Full list of author information is available at the end of the article
}

spillages, impacting the terrestrial ecosystem, occur due to vandalization of the pipelines. In Nigeria, a total number of 2097 oil spill incidents were recorded between 1997 and 2001(Renner et al. 2008). In 2005, 117 cases of fire outbreak were recorded as a result of pipeline vandalization and rupture of Nigerian National Petroleum Corporation (NNPC) pipelines (Renner et al. 2008). According to Shell Petroleum Development Company of Nigeria Limited, in the Niger Delta region alone, 1301 oil spill incidents were recorded around SPDC facilities between 2007 and March 2013 resulting from equipment failure, corrosion or human error (Doherty, 2014) Lagos State contains networks of petroleum distribution pipelines, depots, and 
petrol filling stations, with underground tanks which leak petroleum products into the terrestrial environment. Occasionally, accidental discharges of petroleum products occur due to damage of distribution pipelines. A notable instance of this was the damage of Nigeria National Petroleum Corporation distribution pipeline, which led to large releases of petroleum products into the surrounding environment, causing contamination and subsequent fire outbreak at Ijegun. Doherty and Otitoloju (2013) monitored and determined the soil contamination following the pipeline explosion and spillage of petroleum products in Ijegun. In year 2000, there was a leakage from an oil pipeline which occurred at a freshwater environment in the Niger Delta region of Nigeria known as the Diebu Creek field. Forests, agricultural land and food crops were destroyed by the oil spill (Daniel-Kalio and Braide 2004).

High levels of the monocyclic aromatic hydrocarbons such as benzene, toluene, ethylbenzene, and xylene (BTEX) have been reported in different areas of the environment by researchers (Akpoborie et al. 2008; De Oliveira et al. 2007; Guimaraes et al. 2010; Osu and Asuoha 2010; Osuji and Achugasim 2010). In areas where there are frequent incidences of petroleum products spillage, BTEX are reported as major compounds causing environmental pollution. The consistent pollution of the environment of Lagos with monocyclic aromatic hydrocarbons, represented by BTEX, necessitates constant monitoring and assessment of their impacts. BTEX compounds have higher solubility in water than the aliphatics, which are the other organic compounds known to be present in gasoline (Farhadian et al. 2008). A large percentage of petroleum products is made up of BTEX, which is about $18 \%$ in standard gasoline essentially because they are added to unleaded petroleum products to increase fuel performance (Budavari 1996). The main concern over BTEX is their volatile nature, and ability to migrate away from the original areas of pollution.

Soil pollution by gasoline has become a significant environmental concern due to its adverse ecological effects. Concentrations of BTEX compounds ranging from 0.001 to $0.013 \mathrm{mg} / \mathrm{kg}$ have been detected in soil samples collected from automobile mechanic workshops (Osu and Asuoha 2010). BTEX compounds are well-known toxicants to a wide range of terrestrial biota as well as aquatic organisms ( $\mathrm{Au}, 2004)$. BTEX, like other hydrocarbons, have a high degree of lipophilicity which enables them to penetrate biological cell membranes and leading to their concentration in fatty deposits (Doherty, 2014). The potential toxicity of BTEX compounds is linked to their lipophilicity. Even though these toxic components are sometimes present at sublethal levels, they can cause carcinogenic effects, asthma, aplastic anemia, morphological abnormalities in earthworms, neurological effects, leukemia, and decreased sperm vitality and motility (ASTDR, 2006).
The need to detect and assess the impact of pollution, particularly low concentrations of contaminants, on environmental quality has led to the development of biological markers. Biochemical biomarkers are increasingly used in ecological risk assessment of the ecosystem to identify the incidence and effects of xenobiotics. This is because of their potential to act as early warning signal against potentially damaging effects caused by stressors (Doherty, 2014). Ideally, biochemical biomarkers will identify effects at subcellular level before they are apparent at higher levels of biological organization (Olsen et al. 2001). Hydrocarbons can cause oxidative stress through the generation of reactive oxygen species (ROS) (Ziech et al., 2010). This will have harmful effects on the cells through deoxyribonucleic acid (DNA) damage, protein oxidation, and lipid peroxidation (Ziech et al. 2010). These harmful effects can be prevented when antioxidant systems are produced to eliminate ROS; the organism in contaminated environment is, therefore, able to overcome the oxidative stress when this occurs (Ahmad et al. 2004). This antioxidant defense system comprises of antioxidant molecules, such as glutathione (GSH), catalase (CAT), glutathione S-transferase (GST), and superoxide dismutase (SOD), which can serve as biomarkers of oxidative stress. Lipid peroxidation has a good correlation with ROS generation, and it is regarded as an important indicator of the oxidative stress level (Valavanidis et al. 2006). Oxidative stress as a result of environmental pollution has been documented in numerous organisms (Mohamed et al. 2008; Nogueira et al. 2010; Padmini et al. 2009; Valavanidis et al. 2006).

The Eudrilus eugeniae (earthworm) is an important organism at the bottom of the terrestrial trophic food chain, and it plays a key role in ecotoxicological tests as a sensitive biomonitor of soil pollution. They have been broadly used to assess environmental impact from pollution, and they are typical test organisms in standardized toxicity tests (Sanchez-Hernandez, 2006). Earthworms are common in a wide range of soils and may represent $60 \pm 80 \%$ of the total soil biomass (Saint-Denis et al. 2001). This makes them one of the most suitable bioindicator organisms for testing chemicals in soils. Earthworms have been used to assess soil health through both acute and sub-lethal ecotoxicity tests. Reports have shown that pollutants can induce an increase in reactive oxygen species (ROS) in earthworms (SaintDenis et al. 2001; Xiao et al. 2006). Induction or inhibition of the antioxidant enzymatic system is considered valid biomarkers of environmental pollution in earthworm toxicology (Song et al., 2009). Histopathological responses in earthworms have also been reported as valuable markers of toxicity (Bansiwal and Rai 2010; Kilic, 2011).

Additionally, the exposure of organisms to pollutants also induces a number of lesions in different organs which can act as histopathological markers when biological systems are exposed to petroleum-product related stressors 
(Valavanidis et al. 2006). These histopathological markers are biologically important endpoints and can act as a measure of environmental toxicity that an organism has been exposed to. It is necessary to establish dose-response relationships where indigenous organisms are exposed to different concentrations in order to establish toxicity indices which can be used as a tool for hydrocarbon pollution diagnosis and management, particularly for the formation of environmental safe standards for BTEX fractions in Nigeria (Doherty, 2014).

In view of the problems mentioned above, the aim of this study was to establish lethal concentrations of BTEX, identify changes caused by BTEX compounds to the histology and antioxidant defense systems in E. eugeniae (earthworm). This can be used as a group of biomarkers for early detection of pollution associated with petroleum hydrocarbon, and also petroleum-product pollution monitoring programs in Nigeria. The results of the acute toxicity study of BTEX on E. eugeniae (earthworm) will assist regulatory agencies in establishing environmental safe limits and standards for BTEX (using indigenous species) in developing countries like Nigeria. The sub-lethal tests carried out will also provide information on the health status of E. eugeniae (earthworm) in the contaminated area of Ijegun, Lagos State, through determination of histopathological effects and biochemical responses.

\section{Materials and methods \\ Field and laboratory studies \\ Description of ljegun site}

Ijegun is a suburban area, located in Alimosho Local Government Area, in Lagos State, Nigeria. It is within longitude $3^{\circ} 4.0^{\prime}$ East and latitude $6^{\circ} 28.8^{\prime}$ and $6^{\circ} 8.0^{\prime}$ North

\section{Test chemicals}

Benzene: Puriss. P.a., $\geq 99.7 \%$, Toluene: Laboratory Reagent, $\geq 99.3 \%$, Xylene: Puriss. P.a., $\geq 99.0 \%$ and Ethylbenzene: All Laboratory Reagents were obtained from Sigma Aldrich. The BTEX compounds were chosen for this study because they are toxic in nature and constitute a major percentage of petroleum products, and also due to the carcinogen benzene. The focus on BTEX compounds was also due to frequent spillage of petroleum products and consequent release of these toxic chemicals into the surrounding environment in Nigeria.

\section{Sources and collection of E. eugeniae (class: Clitellata, order: Haplotaxida, family: Eudrilidae)}

Earthworms, E. eugeniae (Kinberg 1867) were collected from around the oil spill contaminated sites in Ijegun and from the University of Lagos Zoological and Botanical garden (to serve as control); they were taken live to the laboratory for biochemical and histopathological studies. Sexually matured earthworms were collected from Ijegun for field studies, and University of Lagos Zoological and Botanical garden for the laboratory studies. The earthworms were collected from the following stations (S) in Ijegun: S5, S6, S8, S9, S12, S13, S18, and S19 (Table 1) by carefully handpicking them into containers. The earthworms were collected with the soil from the habitat to the laboratory for acclimatization and further analysis. The earthworms were retained in glass containers (volume of $5 \mathrm{l}$ ) which contained loamy and humus soil mixed and augmented with steamed, ground water-leaf (Talinum triangulare) and dampened with water following the method of Fafioye and Owa (2000). The glass containers were adequately covered with plastic lid with ventilation holes (OECD (Organisation for Economic Cooperation and Development), 1984). E. eugeniae collected from the control site were kept in the containers for 10 days to acclimatize to laboratory conditions. However, the exposed earthworms from the field were immediately taken for further biochemical and histopathological analyses. The animals were fed with leaflets of lettuce Nymphea lotus every 4 days during acclimatization in the laboratory after Otitoloju (2005). E. eugeniae of same sizes between 80 and $120 \mathrm{~mm}$ in length, and body weight of between 0.9 and $1.2 \mathrm{~g}$ were chosen from the containers to be used for the experiment.

\section{Acute toxicity studies}

In the bioassay for the earthworms, test media were made up of $1000 \mathrm{~g}$ of soil to hold 10 earthworms per bioassay container in 3 replicates. Active E. eugeniae of similar sizes from pre-bioassay holding tanks were randomly distributed into bioassay tanks already holding benzene, toluene, ethylbenzene, and xylene each and untreated control medium. Each treatment had 3 replicates.

(a). Benzene against $E$. eugeniae at 0.5, 1.0, 2.0, $4.0 \mathrm{mg}$ and control.

(b). Toluene against E. eugeniae at $0.3,0.5,1.0,2.0 \mathrm{mg}$ and control.

Table 1 Global positioning system (GPS) reading of the sampling stations

\begin{tabular}{ll}
\hline Code & GPS \\
\hline S5 & $N^{\circ} 6^{\circ} 31^{\prime} 60.6^{\prime \prime} \mathrm{E} 003^{\circ} 16^{\prime} 07.0^{\prime \prime}$ \\
S6 & $N 06^{\circ} 31^{\prime} 68.5^{\prime \prime} \mathrm{E} 003^{\circ} 15^{\prime} 86.5^{\prime \prime}$ \\
S8 & $\mathrm{N} 06^{\circ} 31^{\prime} 60.0^{\prime \prime} \mathrm{E} 003^{\circ} 15^{\prime} 96.6^{\prime \prime}$ \\
S9 & $\mathrm{N} 06^{\circ} 31^{\prime} 51.0^{\prime \prime} \mathrm{E} 003^{\circ} 16^{\prime} 07.3^{\prime \prime}$ \\
S12 & $\mathrm{N} 06^{\circ} 31^{\prime} 49.8^{\prime \prime} \mathrm{E} 003^{\circ} 15^{\prime} 89.6^{\prime \prime}$ \\
S13 & $\mathrm{N} 06^{\circ} 31^{\prime} 52.5^{\prime \prime} \mathrm{E} 003^{\circ} 15^{\prime} 91.8^{\prime \prime}$ \\
S18 & $\mathrm{N} 06^{\circ} 31^{\prime} 60.0^{\prime \prime} \mathrm{E} 003^{\circ} 15^{\prime} 48.8^{\prime \prime}$ \\
S19 & $\mathrm{N} 06^{\circ} 31^{\prime} 61.0^{\prime \prime} \mathrm{E} 003^{\circ} 14^{\prime} 72.3^{\prime \prime}$ \\
\hline
\end{tabular}


(c). Ethylbenzene against E. eugeniae at 0.3, 1.0, 1.50, $2.0 \mathrm{mg}$ and control.

(d). Xylene against E. eugeniae at 0.3, 0.5, 1.0, $2.0 \mathrm{mg}$ and control.

Assessment was done once in $24 \mathrm{~h}$ for the 7 -day period.

\section{Preparation of substrate for the laboratory studies}

A blend of soil made up of loamy and humus soil was taken from the zoological and botanical garden in the University of Lagos and used as substrate. Air-dried soil, ground, and sieved with $0.25 \mathrm{~mm}$ (mesh size) screen was used in order to have uniform grain size. One thousand grams of the prepared soil was used for the bioassay. To establish the appropriate concentration for testing chemical, preliminary screening was carried out. Micropipette was used to measure pre-determined concentrations of test chemicals into bioassay containers with the soil substrate. For uniform distribution of the chemicals, the substrate and test chemicals were properly mixed (Doherty, 2014).

\section{Measurements of physico-chemical parameters of soil used as test media}

Potassium, magnesium, calcium, sodium, conductivity, and nitrogen were determined following standard methods (Motsara and Roy 2008). The determination of total organic content of soil samples was carried out by furnace method as described by (Doherty, 2014). The loss of weight after ignition in the furnace was calculated and the percentage combustible material (total organic content) was estimated as:

$$
\% \text { Total Organic Content }=\frac{\text { loss in weight on ignition }}{\text { initial weight of soil before ignition }}
$$

\section{Chronic toxicity studies}

Rectangular glass containers $(15 \mathrm{~cm} \times 15 \mathrm{~cm} \times 15 \mathrm{~cm})$ were used as bioassay containers; test media were made up of $1000 \mathrm{~g}$ of soil substrate to hold twelve earthworms per bioassay container in three replicates. This bioassay test was conducted for 28 days according to standard procedure (OECD (Organisation for Economic Cooperation and Development), 1984). Sub-lethal concentrations of test chemicals were calculated as fractions (1/ 10th, 1/100th) of the obtained $\mathrm{LC}_{50}$ as follows:

(a). Benzene against E. eugeniae at:

$$
1.9 \mathrm{ml} \times 1 / 10=0.19 \mathrm{mg} / \mathrm{kg}
$$

$1.9 \mathrm{ml} \times 1 / 100=0.019 \mathrm{mg} / \mathrm{kg}$

(b). Toluene against E. eugeniae at:

$$
\begin{aligned}
& 1.3 \mathrm{ml} \times 1 / 10=0.13 \mathrm{mg} / \mathrm{kg} \\
& 1.3 \mathrm{ml} \times 1 / 100=0.013 \mathrm{mg} / \mathrm{kg}
\end{aligned}
$$

(c). Ethylbenzene against E. eugeniae at:

$$
\begin{aligned}
& 1.4 \mathrm{ml} \times 1 / 10=0.14 \mathrm{mg} / \mathrm{kg} \\
& 1.4 \mathrm{ml} \times 1 / 100=0.014 \mathrm{mg} / \mathrm{kg}
\end{aligned}
$$

(d). Xylene against E. eugeniae at:

$$
\begin{aligned}
& 1.2 \mathrm{ml} \times 1 / 10=0.12 \mathrm{mg} / \mathrm{kg} \\
& 1.2 \mathrm{ml} \times 1 / 100=0.012 \mathrm{mg} / \mathrm{kg}
\end{aligned}
$$

\section{Preparation of homogenate}

At pre-determined time intervals (day 0, 2, 7, 15, 21, 28), five live earthworms were selected randomly for further analyses. The earthworms were quickly removed and prepared as follows: The animals were cleansed in icecold $1.15 \%$ potassium chloride $\mathrm{KCl}$ solution and then homogenized in homogenizing buffer of 4 volumes (50 $\mathrm{mM}$ Tris- $\mathrm{HCl}$ mixed with $1.15 \% \mathrm{KCl}$ and $\mathrm{pH}$ adjusted to 7.4), using Teflon Homogenizer.

\section{Measurement of antioxidant enzymes and non-enzymes in exposed earthworms from the field and laboratory}

The following antioxidant enzyme studies were carried out on E. eugeniae that were exposed to sub-lethal concentrations of BTEX: superoxide dismutase (SOD) activity was investigated by its ability to inhibit the auto-oxidation of epinephrine determined by the increase in absorbance at $480 \mathrm{~nm}$ according to Sun and Zigma (1978). Catalase enzyme assay (CAT) was determined adopting the methods of Sun and Zigma (1978), and hydrogen peroxide was prepared with phosphate buffer. Glutathione Stransferase (GST) activity was carried out according to Habig et al.(1974) using 1 chloro 2,4 dinitrobenzene as substrate. Malondialdehyde (MDA), an index of lipid peroxidation, was determined according to Buege and Aust 
(1978). The reduced glutathione (GSH) content was estimated according to the method described by Sedlak and Lindsay (1968).

\section{Histopathology}

The earthworms, E. eugeniae, exposed to sub-lethal concentrations of BTEX in the laboratory and those collected from the oil impacted site were dissected, and the transverse sections through the middle were prepared for histopathological analysis. They were fixed in Bouin's fluid for $24 \mathrm{~h}$, washed with $70 \%$ ethanol and dehydrated through a graded series of ethanol (Schalm et al. 1975).

\section{Statistical analysis}

The probit analysis was carried out using SPSS 14.0. One-way analysis of variance (ANOVA) was used to analyze data. Differences at $P<0.05$ were considered significant, and used to compare several treatment means in appropriately designed experiments. Post hoc tests were performed when significant variations were detected. SPSS 15.0 computer software package and Excel 2007 were used to analyze data.

\section{Results}

Physico-chemical parameters of bioassay during toxicity testing

The result of physic-chemical characteristics of soil used as substrate in the bioassays showed that $\mathrm{pH}$ was 6.5, phosphorus was $0.68 \mathrm{mg} / \mathrm{kg}$, and total organic content (TOC) was $0.02 \%$. Potassium, magnesium, calcium, and sodium had the following values $30.04 \mathrm{mg} / \mathrm{kg}, 282.72$ $\mathrm{mg} / \mathrm{kg}, 518.32 \mathrm{mg} / \mathrm{kg}$, and $55.58 \mathrm{mg} / \mathrm{kg}$ respectively. Nitrogen was $0.001 \%$ and conductivity was $115 \mathrm{uscm}^{-1}$.

\section{Acute toxicity of BTEX compounds against $E$. eugeniae}

On the basis of $96 \mathrm{~h} \mathrm{LC}_{50}$ values, xylene was the most toxic compound tested against E. eugeniae, with value of $1.212 \mathrm{mg} / \mathrm{kg}$, followed by toluene, ethylbenzene, and benzene $\left(96 \mathrm{~h} \mathrm{LC} \mathrm{L}_{50}=1.896 \mathrm{mg} / \mathrm{kg}\right)$ in a descending order of toxicity (Table 2$)$. Computed toxicity factor $\left(96 \mathrm{hLC}_{50}\right.$ ratios) showed that xylene was about 1.10x, 1.13x, 2.41x, more toxic than toluene, ethylbenzene and benzene respectively when tested against E. eugeniae (Table 2).

\section{Chronic toxicity studies \\ Antioxidant enzymes and non-enzymes in E. eugeniae exposed to sub-lethal concentrations of benzene, toluene, ethylbenzene, and xylene}

Glutathione level The levels of GSH in the earthworms exposed to high (1/10th of $\left.\mathrm{LC}_{50}\right)$ and low (1/100th of the $\mathrm{LC}_{50}$ ) sub-lethal concentrations, over a period of 28 days are presented in Tables 3 and 4. Earthworms exposed to high concentration of benzene showed that GSH activity decreased significantly $(P<0.05)$ on days 2 and 7, from day 0 (28.64 $\pm 1.47 \mathrm{~nm} / \mathrm{mg}$ protein), followed by a sudden increase on days 15 and 28. Earthworms exposed to low concentration of benzene also showed similar pattern, but the values of the GSH activity was higher. Earthworms exposed to high and low concentrations of toluene showed a decrease on day 2, followed by a sharp increase in days 7 and 15, which later dropped on days 21 and 28. Earthworms exposed to high and low concentrations of ethylbenzene and xylene showed a decrease following day 0 . The values observed on day 28 from both chemical exposures were lower than the values observed on day 0 . Benzene had a significant effect $(p<0.05)$ on the concentration of GSH. At day 28, there was a decrease of $48.37 \%$ after exposure to high concentration of toluene and a decrease of $40.75 \%$ after exposure to low concentration of toluene. The percentage decrease at day 28 was $45.87 \%$ for the high concentration and $20.11 \%$ for the low concentration of ethylbenzene. The percentage decrease in the levels of GSH (day 0 to 28) in earthworms exposed to xylene at high and low concentrations were $37.36 \%$ and $41.16 \%$ respectively.

Superoxide dismutase (SOD) activity The levels of SOD in the earthworms exposed to high (1/10th of $\left.\mathrm{LC}_{50}\right)$ and low (1/100th of the $\left.\mathrm{LC}_{50}\right)$ sub-lethal concentrations, over a period of 28 days are presented in Tables 3 and 4 . Earthworms exposed to high and low concentrations of benzene and toluene showed that SOD activity decreased significantly $(P<0.05)$ on days 2 to 28 from day 0 . The percentage decrease of SOD activities from day 0 to day 28 in earthworms exposed to benzene at high and low concentration were $58.71 \%$ and $59.16 \%$ respectively. The percentage decreases of SOD activities at day 28 in earthworms exposed to toluene at high concentration was $88.32 \%$, and

Table 2 Comparative acute toxicity of benzene, toluene, ethylbenzene, and xylene acting singly against E. eugeniae

\begin{tabular}{lllll}
\hline Test chemicals & $\mathrm{LC}_{50}(95 \% \mathrm{CL})$ & Slope \pm S.E. & Probit line equation & T.F. \\
\hline Benzene & $1.896(4.600-1.046)$ & $1.792 \pm 0.669$ & $Y=-0.498+1.792 x$ & $Y .41$ \\
Toluene & $1.335(4.565-0.824)$ & $2.129 \pm 0.755$ & $Y=-0.267+2.129 x$ & 1.10 \\
Ethylbenzene & $1.366(2.632-0.861)$ & $2.502 \pm 0.874$ & $Y=-0.338+2.502 x$ & 1.13 \\
Xylene & $1.212(3.292-0.758)$ & $2.191 \pm 0.751$ & $Y=-0.183+2.191 \times$ & 1.00 \\
\hline
\end{tabular}

C.L. 95\% confidence limit, S.E Standard error, T.F Toxicity factor

T.F Toxicity factor $=96 \mathrm{~h} \mathrm{LC}{ }_{50}$ value of other chemical

$96 \mathrm{~h} \mathrm{LC}_{50}$ value of most toxic chemical 
Table 3 Biochemical responses of E. eugeniae exposed to benzene and toluene contaminated soil

\begin{tabular}{|c|c|c|c|c|c|}
\hline \multirow[t]{2}{*}{ Biochemical measurements } & \multirow[t]{2}{*}{ Duration of exposure (days) } & \multicolumn{2}{|c|}{ Benzene concentration } & \multicolumn{2}{|c|}{ Toluene concentration } \\
\hline & & High (1/10th) & Low (1/100th) & High (1/10th) & Low (1/100th) \\
\hline \multirow[t]{6}{*}{ GSH } & 0 & $28.64 \pm 1.47$ & $28.64 \pm 1.47$ & $28.64 \pm 1.47$ & $28.64 \pm 1.47$ \\
\hline & 2 & $12.27 \pm 1.22^{*}$ & $20.29 \pm 1.30$ & $10.73 \pm 0.84^{*}$ & $13.81 \pm 0.91^{*}$ \\
\hline & 7 & $12.51 \pm 4.03^{*}$ & $16.70 \pm 1.23$ & $31.84 \pm 1.1^{*}$ & $32.77 \pm 1.08^{*}$ \\
\hline & 15 & $33.58 \pm 2.89^{*}$ & $62.32 \pm 32.13^{*}$ & $31.47 \pm 1.04^{*}$ & $32.98 \pm 1.35^{*}$ \\
\hline & 21 & $27.04 \pm 1.18$ & $29.36 \pm 1.04$ & $13.08 \pm 1.31^{*}$ & $19.11 \pm 1.04$ \\
\hline & 28 & $34.52 \pm 1.48^{*}$ & $37.02 \pm 0.77$ & $16.22 \pm 1.25^{*}$ & $16.97 \pm 1.15$ \\
\hline \multirow[t]{6}{*}{ SOD } & 0 & $235.20 \pm 30.41$ & $235.20 \pm 30.41$ & $235.20 \pm 30.41$ & $235.20 \pm 30.41$ \\
\hline & 2 & $105.46 \pm 8.65^{*}$ & $195.75 \pm 7.87^{*}$ & $81.94 \pm 27.7^{*}$ & $69.88 \pm 9.16^{*}$ \\
\hline & 7 & $94.84 \pm 5.36^{*}$ & $45.52 \pm 11.06^{*}$ & $50.07 \pm 12.41^{*}$ & $68.28 \pm 8.48^{*}$ \\
\hline & 15 & $94.84 \pm 5.36^{*}$ & $45.52 \pm 11.06^{*}$ & $182.54 \pm 2.9^{*}$ & $64.64 \pm 5.11^{*}$ \\
\hline & 21 & $115.70 \pm 6.00^{*}$ & $124.73 \pm 9.47^{*}$ & $64.11 \pm 4.37^{*}$ & $72.08 \pm 6^{*}$ \\
\hline & 28 & $97.11 \pm 9.52^{*}$ & $96.05 \pm 7.41^{*}$ & $39.23 \pm 11.92$ & $170.71 \pm 24.88$ \\
\hline \multirow[t]{6}{*}{ CAT } & 0 & $693.00 \pm 78.85$ & $693.00 \pm 78.85$ & $693 \pm 42.15$ & $693 \pm 42.15$ \\
\hline & 2 & $449.75 \pm 84.29^{*}$ & $585.90 \pm 94.28^{*}$ & $470.05 \pm 64.89^{*}$ & $489.3 \pm 86.27$ \\
\hline & 7 & $288.75 \pm 19.57^{*}$ & $93.45 \pm 7.38^{*}$ & $196 \pm 38.12^{*}$ & $248.5 \pm 64.77^{*}$ \\
\hline & 15 & $288.75 \pm 19.57^{*}$ & $93.45 \pm 7.38^{*}$ & $175.35 \pm 16.94^{*}$ & $214.55 \pm 24.52^{*}$ \\
\hline & 21 & $399.00 \pm 33.66^{*}$ & $506.10 \pm 28.93$ & $156.8 \pm 12.53^{*}$ & $225.4 \pm 29.58^{*}$ \\
\hline & 28 & $354.90 \pm 30.75^{*}$ & $430.85 \pm 39.02$ & $485.8 \pm 62.04^{*}$ & $429.8 \pm 85.49$ \\
\hline \multirow[t]{6}{*}{ MDA } & 0 & $2.46 \pm 0.12$ & $2.46 \pm 0.12$ & $2.46 \pm 0.12$ & $2.46 \pm 0.12$ \\
\hline & 2 & $7.81 \pm 0.11^{*}$ & $4.74 \pm 0.28$ & $6.8 \pm 0.72^{*}$ & $4.05 \pm 0.52^{*}$ \\
\hline & 7 & $3.23 \pm 0.06^{*}$ & $1.78 \pm 0.07^{*}$ & $2.95 \pm 0.13$ & $2.32 \pm 0.16$ \\
\hline & 15 & $3.23 \pm 0.06^{*}$ & $1.78 \pm 0.07^{*}$ & $3.03 \pm 0.16$ & $2.32 \pm 0.15$ \\
\hline & 21 & $0.42 \pm 0.10^{*}$ & $0.23 \pm 0.04^{*}$ & $0.52 \pm 0.12^{*}$ & $1.37 \pm 0.15^{*}$ \\
\hline & 28 & $2.75 \pm 0.15^{*}$ & $1.74 \pm 0.11^{*}$ & $1.62 \pm 0.82$ & $1.78 \pm 0.13$ \\
\hline \multirow[t]{6}{*}{ GST } & 0 & $395.77 \pm 20.30$ & $395.77 \pm 20.30$ & $395.77 \pm 20.30$ & $395.77 \pm 20.30$ \\
\hline & 2 & $395.77 \pm 20.30$ & $418.27 \pm 6.32^{*}$ & $274.96 \pm 16.6^{*}$ & $246.21 \pm 15.55$ \\
\hline & 7 & $280.37 \pm 17.95^{*}$ & $169.56 \pm 16.83^{*}$ & $234.55 \pm 13.06^{*}$ & $190.8 \pm 12.55^{*}$ \\
\hline & 15 & $363.69 \pm 14.17$ & $667.39 \pm 29.70^{*}$ & $434.93 \pm 14.31^{*}$ & $453.68 \pm 19.4^{*}$ \\
\hline & 21 & $373.90 \pm 16.20^{*}$ & $405.77 \pm 10.66^{*}$ & $181.22 \pm 17.34^{*}$ & $264.12 \pm 14.31$ \\
\hline & 28 & $477.01 \pm 20.46$ & $511.58 \pm 14.40^{*}$ & $224.13 \pm 18.8^{*}$ & $234.55 \pm 15.84$ \\
\hline
\end{tabular}

CAT Catalase, MDA Malondialdehyde, GSH Total glutathione, GST Glutathione-S-transferase, SOD Superoxide dismutase; statistical significance, treated versus control group:* $(p<0.05)$. Results are expressed as means \pm standard deviations $(n=5)$

low concentrations were $27.42 \%$. There was also similar pattern of decrease in earthworms exposed to ethylbenzene and xylene. There was a sharp increase from day 21 to 28 in earthworms exposed to low concentration of xylene. The percentage decreases of SOD activities at day 28 in earthworms exposed to ethylbenzene at high and low concentrations were $5.06 \%$ and $42.29 \%$ respectively while the percentage decrease of SOD activities at day 28 in earthworms exposed to xylene at high concentration was $16.58 \%$.

Catalase activity The activity of CAT in the earthworms exposed to high (1/10th of $\left.\mathrm{LC}_{50}\right)$ and low (1/ 100th of the $\mathrm{LC}_{50}$ ) sub-lethal concentrations, over a period of 28 days is presented in Tables 3 and 4. Earthworms exposed to high and low concentrations of benzene, toluene, ethylbenzene, and xylene showed that CAT activity decreased significantly $(P<0.05)$ on days 2 to 28 from $693 \mathrm{u} / \mathrm{mg}$ protein recorded on day 0 . The percentage decreases of CAT activity at day 28 in earthworms exposed to benzene at high and low concentrations were $48.78 \%$ and $37.83 \%$ respectively. The percentage decrease in CAT activity at day 28 in earthworms exposed to toluene high concentration was $29.90 \%$, and low concentration was $37.98 \%$. The percentage decrease in CAT activity at day 28 in earthworms 
Table 4 Biochemical responses of E. eugeniae exposed to ethyl benzene and xylene contaminated soil

\begin{tabular}{|c|c|c|c|c|c|}
\hline \multirow[t]{2}{*}{ Biochemical measurements } & \multirow[t]{2}{*}{ Duration of exposure (days) } & \multicolumn{2}{|c|}{ Ethylbenzene concentration } & \multicolumn{2}{|c|}{ Xylene concentration } \\
\hline & & High (1/10th) & Low (1/100th) & High (1/10th) & Low (1/100th) \\
\hline \multirow[t]{6}{*}{ GSH } & 0 & $28.64 \pm 1.47$ & $28.64 \pm 1.47$ & $28.64 \pm 1.47$ & $28.64 \pm 1.47$ \\
\hline & 2 & $16.1 \pm 2.22^{*}$ & $13.87 \pm 0.77^{*}$ & $10.76 \pm 0.74^{*}$ & $16.97 \pm 0.94^{*}$ \\
\hline & 7 & $12.84 \pm 0.97^{*}$ & $19.29 \pm 1.08^{*}$ & $16.91 \pm 1.92^{*}$ & $16.4 \pm 1.24^{*}$ \\
\hline & 15 & $57.52 \pm 1.55^{*}$ & $21.74 \pm 4.69^{*}$ & $16.91 \pm 1.92^{*}$ & $16.67 \pm 1.13^{*}$ \\
\hline & 21 & $22.43 \pm 1.6^{*}$ & $13.93 \pm 1.08^{*}$ & $10.25 \pm 1.79^{*}$ & $10.25 \pm 1.34^{*}$ \\
\hline & 28 & $15.5 \pm 1.05^{*}$ & $22.88 \pm 1.28^{*}$ & $17.94 \pm 0.94^{*}$ & $16.85 \pm 1.05^{*}$ \\
\hline \multirow[t]{6}{*}{ SOD } & 0 & $235.20 \pm 30.41$ & $235.20 \pm 30.41$ & $235.20 \pm 30.41$ & $235.20 \pm 30.41$ \\
\hline & 2 & $92.56 \pm 7.39^{*}$ & $139.15 \pm 134.34^{*}$ & $78.3 \pm 20.33^{*}$ & $103.18 \pm 10.59^{*}$ \\
\hline & 7 & $77.92 \pm 6.07^{*}$ & $66.77 \pm 11.25^{*}$ & $98.63 \pm 10.04^{*}$ & $100.15 \pm 5.09^{*}$ \\
\hline & 15 & $41.88 \pm 2.85^{*}$ & $63.96 \pm 4.43^{*}$ & $98.63 \pm 10.04^{*}$ & $98.48 \pm 5.16^{*}$ \\
\hline & 21 & $110.77 \pm 9.82^{*}$ & $114.41 \pm 15.91^{*}$ & $26.72 \pm 13.3^{*}$ & $41.12 \pm 3.24^{*}$ \\
\hline & 28 & $223.29 \pm 12.77^{*}$ & $135.73 \pm 9.17^{*}$ & $196.2 \pm 16.2^{*}$ & $243.54 \pm 41.68$ \\
\hline \multirow[t]{6}{*}{ CAT } & 0 & $693 \pm 42.15$ & $693 \pm 42.15$ & $693 \pm 42.15$ & $693 \pm 42.15$ \\
\hline & 2 & $341.25 \pm 29.02^{*}$ & $413 \pm 56.16^{*}$ & $447.65 \pm 67.05$ & $324.45 \pm 33.24^{*}$ \\
\hline & 7 & $569.8 \pm 44.85$ & $599.55 \pm 55.97^{*}$ & $371 \pm 22.82$ & $605.5 \pm 109.01$ \\
\hline & 15 & $315.7 \pm 5.62^{*}$ & $390.6 \pm 34.86^{*}$ & $371 \pm 22.82$ & $431.2 \pm 48.22$ \\
\hline & 21 & $208.08 \pm 44.87^{*}$ & $220.85 \pm 26.38^{*}$ & $392 \pm 36.29$ & $542.5 \pm 41.04$ \\
\hline & 28 & $371 \pm 41.28^{*}$ & $444.15 \pm 47.68^{*}$ & $451.15 \pm 62.22$ & $482.3 \pm 26.21$ \\
\hline \multirow[t]{6}{*}{ MDA } & 0 & $2.46 \pm 0.12$ & $2.46 \pm 0.12$ & $2.46 \pm 0.12$ & $2.46 \pm 0.12$ \\
\hline & 2 & $7.12 \pm 0.17^{*}$ & $4.87 \pm 0.15^{*}$ & $5.26 \pm 0.33^{*}$ & $4.42 \pm 0.14^{*}$ \\
\hline & 7 & $1.1 \pm 0.14^{*}$ & $1.2 \pm 0.17^{*}$ & $3.27 \pm 0.08^{*}$ & $1.65 \pm 0.11^{*}$ \\
\hline & 15 & $1.12 \pm 0.12^{*}$ & $1.31 \pm 0.15^{*}$ & $3.27 \pm 0.08^{*}$ & $1.69 \pm 0.16^{*}$ \\
\hline & 21 & $8.4 \pm 0.16^{*}$ & $4.56 \pm 0.16^{*}$ & $0.88 \pm 0.08^{*}$ & $0.69 \pm 0.15^{*}$ \\
\hline & 28 & $1.98 \pm 0.2^{*}$ & $1.48 \pm 1.4^{*}$ & $7.83 \pm 0.16^{*}$ & $3.7 \pm 0.15^{*}$ \\
\hline \multirow[t]{6}{*}{ GST } & 0 & $395.77 \pm 20.30$ & $395.77 \pm 20.30$ & $395.77 \pm 20.30$ & $395.77 \pm 20.30$ \\
\hline & 2 & $390.77 \pm 12.2^{*}$ & $400.77 \pm 10.88$ & $428.26 \pm 11.47^{*}$ & $281.62 \pm 13.12$ \\
\hline & 7 & $148.73 \pm 10.27^{*}$ & $148.31 \pm 11.54^{*}$ & $191.64 \pm 10.62^{*}$ & $222.46 \pm 30.73^{*}$ \\
\hline & 15 & $794.87 \pm 21.48^{*}$ & $280.79 \pm 88.16^{*}$ & $225.8 \pm 11.65^{*}$ & $225.38 \pm 9.92^{*}$ \\
\hline & 21 & $309.95 \pm 22.16^{*}$ & $192.47 \pm 14.99^{*}$ & $141.64 \pm 24.78^{*}$ & $141.64 \pm 18.51^{*}$ \\
\hline & 28 & $214.13 \pm 14.46^{*}$ & $316.2 \pm 17.64^{*}$ & $247.88 \pm 13.01^{*}$ & $232.88 \pm 14.54^{*}$ \\
\hline
\end{tabular}

CAT Catalase, MDA Malondialdehyde, GSH total glutathione, GST glutathione-S- transferase, SOD superoxide dismutase; statistical significance, treated versus control group:* $(p<0.05)$. Results are expressed as means \pm standard deviations $(n=5)$.

exposed to ethylbenzene high concentration was $46.50 \%$, and for low concentration was $35.94 \%$. The percentage decreases in CAT activity at day 28 in earthworms exposed to xylene at high and low concentrations were $34.94 \%$ and $30.45 \%$ respectively. There was a sharp increase in day 7 in earthworms exposed to low concentrations of xylene followed by a decrease in the CAT activity.

Glutathione S-transferase activity The activity of GST in the earthworms exposed to high (1/10th of $\mathrm{LC}_{50}$ ) and low $\left(1 / 100\right.$ th of the $\left.\mathrm{LC}_{50}\right)$ sub-lethal concentrations, over a period of 28 days is presented in Tables 3 and 4 . After 28 days, earthworms exposed to high and low concentrations of toluene, ethylbenzene, and xylene showed a significant $(P<0.05)$ decrease in the GST activity. For earthworms exposed to both high and low concentrations of benzene, there were an increase in the GST levels after 28 days. A sharp increase at day 15 in the earthworm exposed in low concentration of benzene was also recorded. The percentage decrease in GST activities at day 28 in earthworms exposed to toluene at high concentration was $43.37 \%$, and low concentration was $40.74 \%$. The percentage decrease in GST activity at day 28 in earthworms exposed to ethylbenzene at low concentration was $20.11 \%$. The percentage decrease in GST activities after 28 days in earthworms exposed to ethylbenzene at high concentration was $45.90 \%$. 
The percentage decreases in GST activity at day 28 in earthworms exposed to xylene at high and low concentrations were $37.37 \%$ and $41.16 \%$ respectively.

Malondialdehyde activity The levels of MDA in the earthworms exposed to high (1/10th of $\left.\mathrm{LC}_{50}\right)$ and low $\left(1 / 100\right.$ th of the $\left.\mathrm{LC}_{50}\right)$ sub-lethal concentrations, over a period of 28 days are presented in Tables 3 and 4 .

After 2 days, earthworms exposed to high and low concentrations of benzene, toluene, ethylbenzene, and xylene showed significant $(P<0.05)$ increase in the activity of MDA. There was subsequent reduction in MDA activity following day 7 through day 28 . However, a sharp increase on day 21 was observed in earthworms exposed to high concentration of ethylbenzene. Benzene had a significant effect $(P<0.05)$ on the level of malondialdehyde (MDA) with percentage increases after day 2 of $217.48 \%$ and 92.68\% in earthworms exposed to high and low concentrations respectively. There was a percentage increase in the level of MDA in earthworms exposed to high concentration of toluene by $176.42 \%$ and a percentage increase of $64.63 \%$ in earthworms exposed to low concentration of toluene. The level of MDA significantly increased by $189.43 \%$ in earthworms exposed to high concentration of ethylbenzene, and $97.97 \%$ in earthworms exposed to low concentration of ethylbenzene after 2 days. The level of MDA significantly increased by $113.82 \%$ and $79.67 \%$ after 2 days in earthworms exposed to high and low concentrations of xylene, respectively.

\section{Histopathological studies in E. eugeniae Control}

The normal architecture of the earthworm, E. eugeniae (collected from control station) consisted of the cuticle, epidermis, intact nature of circular and longitudinal muscles, and subneural vessels. No changes were observed: Lesion, necrosis, pigments, malignancy, inflammation, and inclusion bodies were not observed in the control animals (Plate 1).

\section{Histopathological changes in the body of E. eugeniae exposed to low concentration of BTEX compounds after 28 days}

The histological changes after exposure to low sub-lethal concentrations (1/100th $\left.96 \mathrm{~h} \mathrm{LC}_{50}\right)$ of benzene, toluene, ethylbenzene, and xylene revealed induced marked pathological changes in the body of the earthworm. The changes include cellular degeneration, moderate to severe areas of lesion, necrosis, areas of inflammation, inclusion bodies, pigments, and distortion of the shape of circular and longitudinal muscles. Increase in spaces between the longitudinal muscles, enlargement of ectoderm cells and ruptured cuticle, gradual destruction of ectoderm of body wall, and eroding of internal and external tissues leading to total destruction of body wall were observed (Plate 2ad).

Benzene-Mild necrosis with hypertrophic nerve bundle and endothelial degeneration was noted, with increase of spaces between longitudinal muscles, after exposure of $E$. eugeniae to low concentration of benzene. Toluene-Moderate necrosis and edematous muscles with spaces between longitudinal and circular muscles and acanthotic epidermis was noted after exposure of $E$. eugeniae to low concentration of toluene. Ethylbenzene-Sections showing moderate area of necrosis with obvious cellular degeneration, cloudy swelling of longitudinal and circular muscles, and enlargement of ectoderm cells were observed after exposure of $E$. eugeniae to low concentration of ethylbenzene. Xylene-Sections showing moderate area of necrosis, increase of spaces between longitudinal and circular muscles, and enlargement of ectoderm cells were observed after exposure of E. eugeniae to low concentration of xylene.

\section{Histopathological changes in the body of Eudrilus eugeniae exposed to high concentration of BTEX compounds after 28 days}

The histological changes after exposure to high sublethal concentrations of $1 / 10$ th $96 \mathrm{~h} \mathrm{LC}_{50}$ of benzene, toluene, ethylbenzene, and xylene are shown in Plates 3 a-d. The high sub-lethal concentrations of BTEX compounds also induced severe pathological changes in the body of the earthworm. The changes include cellular degeneration, severe areas of lesion, necrosis, areas of inflammation, inclusion bodies, dark brown pigments, and distortion of the shape of circular and longitudinal muscles. The changes induced as a result of the exposure to high sub-lethal concentrations were more severe compared with those resulting from exposure to low sublethal concentrations of BTEX compounds. Increase of spaces between longitudinal muscles, enlargement of ectoderm cells, ruptured cuticles, gradual destruction of ectoderm of body walls, and eroding of internal and external tissues, leading to total destruction of body walls were observed (Plate 3a-d).

Benzene-Severe necrosis, acanthotic epidermis, and spaces between muscles were noted, with areas of inflammation after exposure of $E$. eugeniae to high concentration of benzene. Toluene-Severe necrosis with areas of inflammation, increase in spaces between longitudinal muscles, and enlargement of ectoderm cells were the changes noted after exposure of $E$. engeniae to high concentration of toluene. Ethylbenzene-Obvious cellular degeneration, ruptured body wall, structural changes of longitudinal and circular muscles, and erosion of tissue resulting in total damage were observed after exposure of $E$. eugeniae to high concentration of ethylbenzene. Xylene-Mild necrosis, with obvious cellular degeneration showing enlargement of 


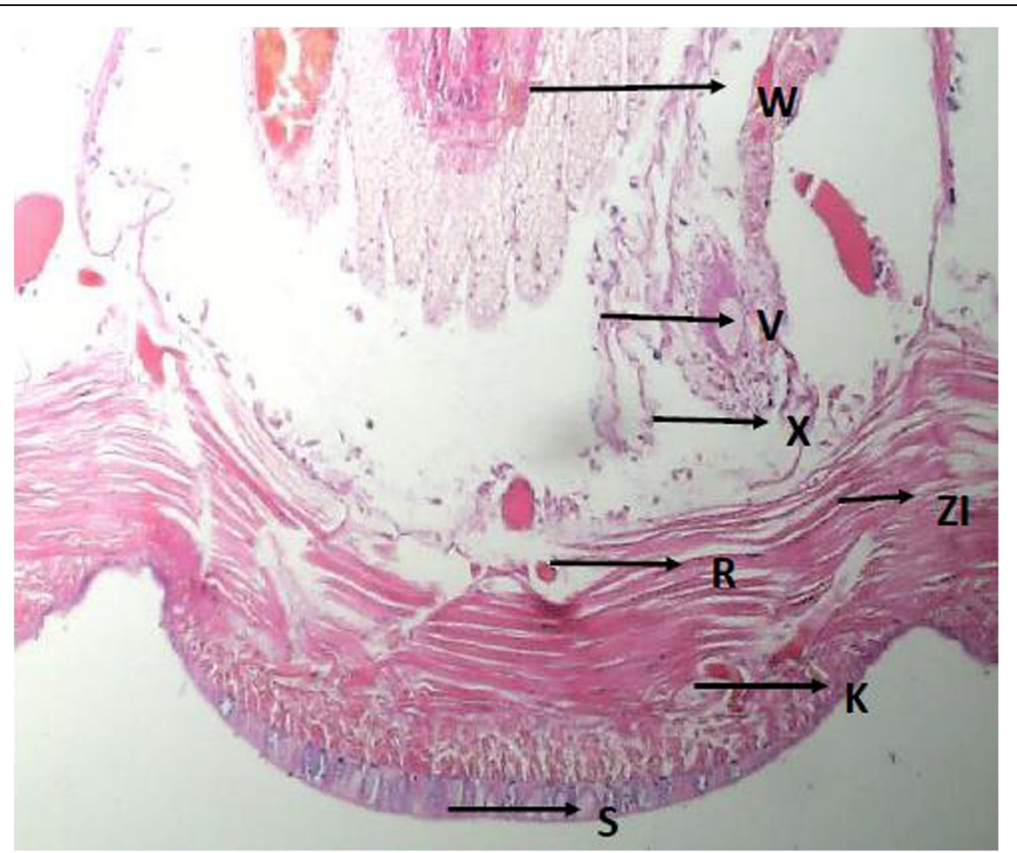

Plate 1 Normal architecture of the earthworm, E. eugeniae collected from the control station: Transverse section through the middle part of the earthworm reveal segmented body cavities, subphenogeal ganglion (K), subneural vessels (R), lining of the esophagus (S), intestine $(V)$, longitudinal and circular muscles (ZI), metanephridium (W), and blood vessels (X). No lesion, no necrosis, no pigments, no malignancy, no inflammation or inclusion bodies seen in the control group. Mag $\times 400$. Control transverse section through the middle part of the earthworm reveal segmented body cavities, subphenogeal ganglion (K), subneural vessels (R), Ectodermal cells (S), intestine ( $V$ ), longitudinal and circular muscles (ZI), metanephridium (W), and blood vessels (X). No lesion, no necrosis, no pigments, no malignancy, no inflammation, or inclusion bodies seen in the control group. $\times 40$ H\&E stain

ectodermal cells, enlargement of spaces between longitudinal and circular muscles, and tissue erosion leading to total damage, as well as detached digestive epithelium were observed after exposure of E. eugeniae to high concentration of xylene.

\section{Histopathological alterations observed in earthworms collected from the impacted site of ljegun}

Plate 4 a-d show the histopathological alterations seen in the internal structures of E. eugeniae collected from the field. The histopathological observations include epidermal and cellular degeneration, presence of inclusion bodies and pigment. Increase in size of ectoderm cells and enlargement of spaces between longitudinal muscles were also observed.

\section{Identified enzymatic, non-enzymatic biomarkers in $E$. eugeniae collected from different stations around oil impacted areas of ljegun}

The activities of antioxidant enzymes and non-enzymes in E. eugeniae collected from the contaminated area of Ijegun are presented in Table 5. The results from the laboratory studies were established in the field studies. Comparing the results of the activities of antioxidant enzymes and non-enzymes in E. eugeniae from the impacted area of Ijegun (Table 5) and the control earthworm, day 0 (Tables 3 and 4), the activities of SOD, GST, CAT, and GSH were inhibited in earthworms collected from Ijegun. It was observed that the levels of GSH, CAT, SOD, and GST in earthworms collected from oil impacted area of Ijegun were significantly lower than the levels of SOD $(235.20 \mathrm{u} / \mathrm{mg}$ protein), CAT $(693.00 \mathrm{u} / \mathrm{mg}$ protein), GSH $(28.64 \mathrm{~nm} / \mathrm{mg}$ protein), and GST $(395.77 \mathrm{~nm} / \mathrm{mg}$ protein) in the control earthworms, day 0 (Tables 3 and 4). The level of MDA was significantly higher in earthworms collected from the oil impacted site than the control earthworm, day $0(2.46 \mathrm{~nm} /$ mg protein) except for few stations like S5, S6, and S8.

SOD activity-SOD activity decreased from $235.20 \mathrm{u} /$ $\mathrm{mg}$ protein in earthworms collected from the control station to 0.76 in earthworms collected from oil impacted station 5 . The percentage decrease was $99.68 \%$. CAT activity-CAT activity decreased from $693.00 \mathrm{u} / \mathrm{mg}$ protein in earthworms collected from the control station to $4.61 \mathrm{u} / \mathrm{mg}$ protein in earthworms collected from oil impacted station. The percentage decrease was $99.33 \%$. GST activity_GST activity decreased from $395.77 \mathrm{~nm} /$ mg protein in earthworms collected from the control station to $0.5 \mathrm{~nm} / \mathrm{mg}$ protein in earthworms collected from oil impacted station 5 . The percentage decrease was $99.87 \%$. Level of GSH-The level of GSH decreased from $28.64 \mathrm{u} / \mathrm{mg}$ protein in earthworms collected from 

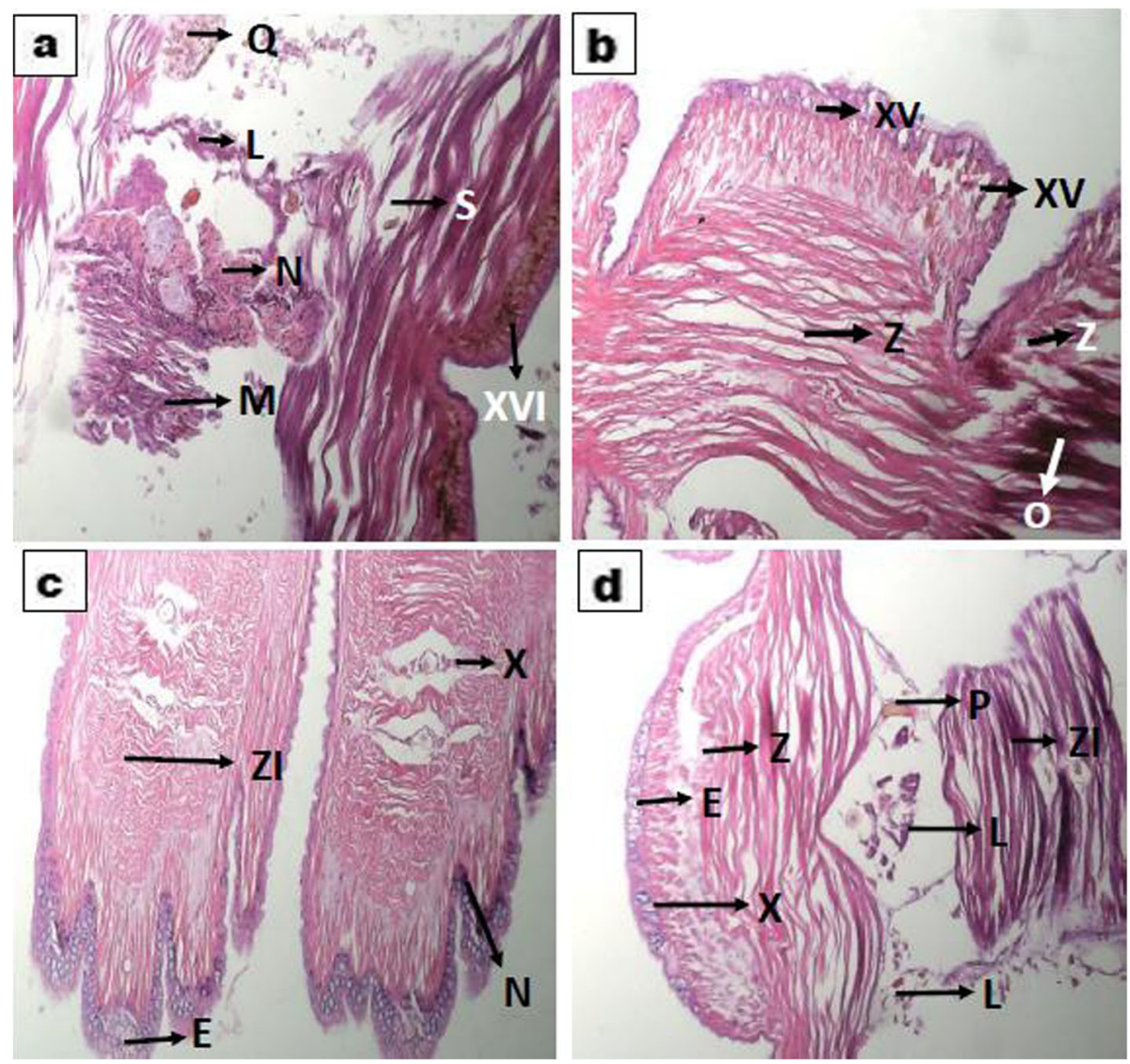

Plate 2 a-d Histopathological (T.S) effects of BTEX (1/100th 96hLC 50 ) after exposure of Eudrilus eugeniae for 28 da5ys (H\&E $\times 400)$. a Benzene, b toluene, $\mathbf{c}$ ethylbenzene, $\mathbf{d}$ xylene. Moderate area of necrosis $(\mathrm{N})$, cellular degeneration $(\mathrm{X})$, cloudy swelling of longitudinal and circular muscles $(Z \mathrm{I})$, enlargement of ectoderm cells (E), dark brown pigment $(\mathrm{O})$, spaces between longitudinal and circular muscles (Z), cellular degeneration with spaces in muscles (XV), enlargement of ectoderm cells (E), moderate area of lesion (L), inclusion bodies (P), Enlargement of ectoderm cells $E$. a-d Photomicrograph of histological section (T.S) effects of BTEX (1/100th $96 \mathrm{~h} \mathrm{LC} \mathrm{C}_{50}$ ) after exposure of Eudrilus eugeniae for 28 days (H\&E stain, $\left.\times 40\right)$

the control station to $0.04 \mathrm{u} / \mathrm{mg}$ protein in earthworms collected from oil impacted station 5 . The percentage decrease was $99.86 \%$. Level of MDA-The level of MDA increased from $2.46 \mathrm{~nm} / \mathrm{mg}$ protein in earthworms collected from the control station to $11.38 \mathrm{~nm} / \mathrm{mg}$ protein in earthworms collected from oil impacted station 18 . The percentage increase was $362.60 \%$.

\section{Discussion}

It is important to note that hydrocarbon contamination was observed in soil samples from all sampled stations including the control station. This indicates that there are other contributory origins of THC in the soil samples collected from the study area. Some of these other sources are likely to be leakages from underground tanks of petrol stations and vehicular emissions. Some authors have observed lower concentrations of THC in contaminated soils and groundwater than the values observed in this study. The level of THC in contaminated soil as a result of oil spill was investigated by Osu and Asuoha (2010) with concentrations of soil samples ranging from 0.601 to $3.678 \mathrm{mg} / \mathrm{kg}$. In another study in Calabar, Nganje et al. (2007) recorded mean THC concentration of $0.66 \mathrm{mg} / \mathrm{l}$ in contaminated well waters which were close to mechanic workshops and petrol stations. The THC levels found in soil samples around the contaminated area of Ijegun in this study were of lesser values than those observed in some studies on the presence and levels of soil hydrocarbons (Ping et al. 2007; Zuo et al. 2007). Mean values of total hydrocarbons from soil samples collected from Tianjin region in China were determined to be lower than $1000 \mu \mathrm{g} / \mathrm{kg}$ (Ye et al. 2006). Several authors have concentrated on soils in the urban areas as an avenue for deposition of hydrocarbons (Iqbal et al. 2007; Wang et al. 2007; Wang et al. 2004; Zhang et al. 2005). These studies have established the fact that urban soils have higher concentrations of hydrocarbon than rural soils.

Results from ecotoxicology studies can be used in the establishment of soil quality criteria for BTEX compounds for the protection of organisms in Nigeria. The 


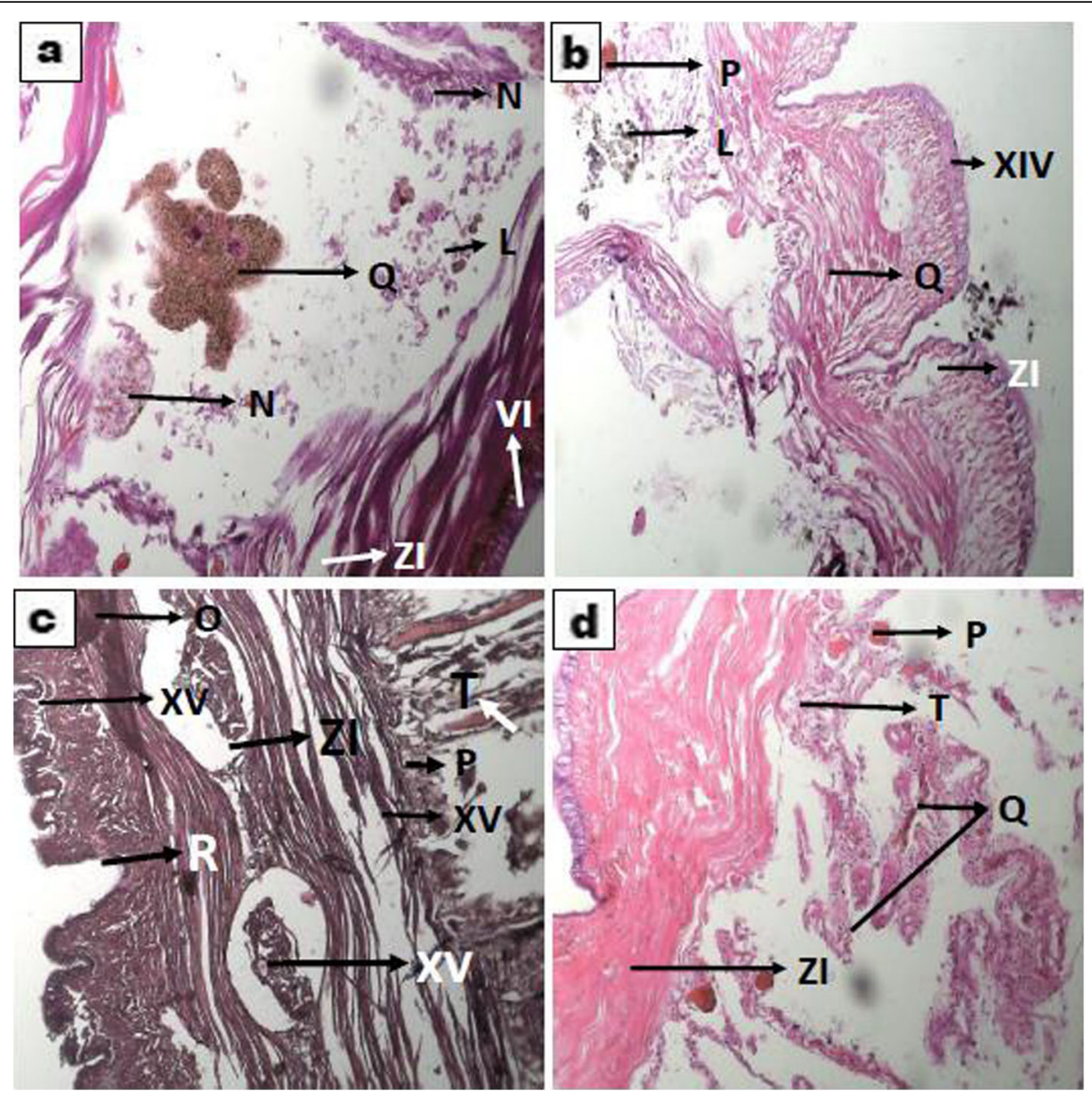

Plate 3 a-d Histopathological (T.S) effects of BTEX (1/10th 96hLC ${ }_{50}$ ) after exposure of Eudrilus eugeniae for 28 days (H\&E $\left.\times 400\right)$. a Benzene, $\mathbf{b}$ toluene, $\mathbf{c}$ ethylbenzene, $\mathbf{d}$ xylene. Severe area of lesion $(\mathrm{L})$, necrosis $(\mathrm{N})$, inclusion bodies $(\mathrm{P})$, epidermis $(\mathrm{Vl})$, area of inflammation $(\mathrm{Q})$, enlargement of ectoderm cells $(X I V)$, dark brown pigment $(\mathrm{O})$, cellular degeneration $(X \mathrm{~V})$, ruptured body wall $\mathrm{R}$, loss of structural integrity of longitudinal and circular muscles (ZI), tissue erosion leading to total damage

lower sensitivity of E. eugeniae (terrestrial organisms) to BTEX compounds is primarily due to the adsorption of BTEX compounds to soil particles, leading to less bioavailability of the monoaromatic hydrocarbons to earthworms in the soil. According to Depledge (1996), different responses to hydrocarbons may also be a consequence of variable tolerances within and among species. Similar observations were made by $\mathrm{An}$ and Lee (2008) and Ogeleka et al. (2010) after exposure of the earthworm, Aporrectodea longa and fish (Tilapia guineensis) to toxicants.

Several researchers on animals have established the significance of antioxidants in defending and protecting the cellular systems from oxidative stress induced by chemicals (Saint-Denis et al. 1999; Song et al. 2009; Valavanidis et al. 2006). Antioxidant enzyme activity may increase or decrease under pollutant pressure, but this depends on the strength/force and the length of the stress applied, in addition to the sensitivity or tolerance of the exposed organisms. A not so perfect balance exists in normal situations between the generation of reactive oxygen species and antioxidant processes. One important area of study for terrestrial toxicology is oxidative stress, and this occurs when there is an imbalance between the prooxidants and antioxidants, resulting in damaging biochemical and physiological effects (Livingstone, 2001). Changes in lipid peroxidation products and activities of antioxidant enzymes can be an indication of oxidative stress.

Increased levels of oxygen species in animal tissues lead to cellular effects when the production level is higher than its decomposition level by antioxidant defense systems. Some researchers have established that measuring levels of lipid peroxide in tissues of animals exposed to various contaminants, can be used as reliable indicators of exposure to environmental stressors and incorporated to environmental surveillance programs (Avci et al. 2005; Fatima and Ahmad, 2005; Valavanidis et al. 2006). Toxic impact can be observed at the sub-cellular stage before it becomes obvious at the higher level of organization in a biological system. Therefore, the significance of using biochemical 

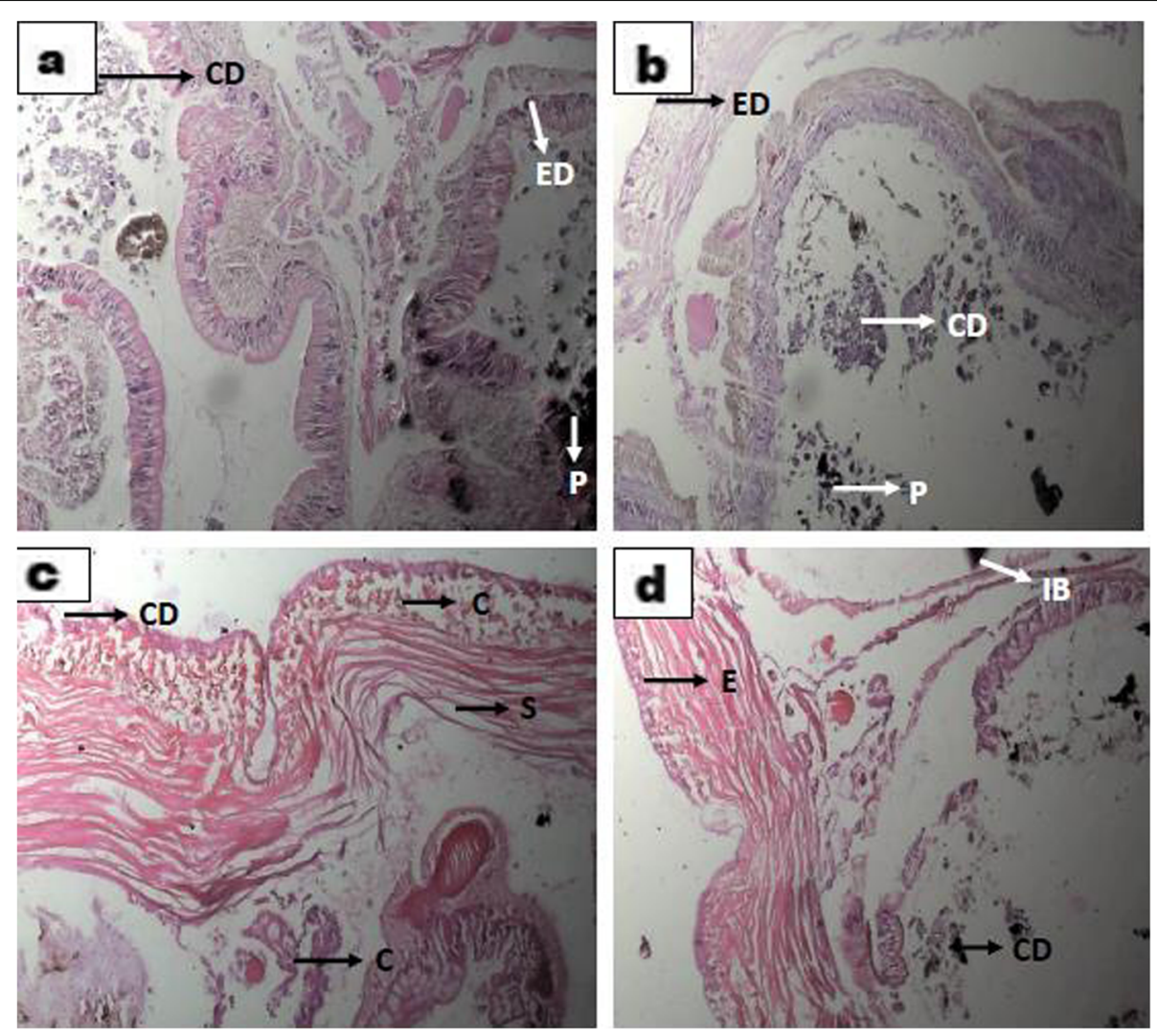

Plate 4 a-d Histopathological (T.S) alterations in E. eugeniae collected from the contaminated area of ljegun. (H\&E $\times 400)$. Cellular degeneration $(C D)$, epidermal degeneration (ED), pigment (P), enlargement of spaces between longitudinal muscles (S), enlargement of ectoderm cells (E), and inclusion bodies (IB)

responses, as biological markers during environmental monitoring programs, cannot be overemphasized. The quantification of these biochemical changes may therefore serve to enhance the evaluation of biologically significant exposures to toxicants.

Earthworms through their skins and alimentary surfaces are continuously exposed to chemicals in the soil. Thus they have a reliable detoxification system for them to survive (Kilic, 2011). Decrease in GSH, SOD, and CAT activities were observed after days of exposure to benzene, toluene, ethylbenzene, and xylene. This result agrees with the findings of Song et al. (2009). They reported overall inhibition in the SOD activity of earthworms and significant stimulation of the activity on the 28th day after exposure to atrazine. The reduction in the SOD activity can result from the destruction of the reactive oxygen species which was transformed to $\mathrm{H}_{2} \mathrm{O}_{2}$ by $\mathrm{SO}$, Multiplication in the SOD activity can be as a result of the generation of $\mathrm{O}_{2}$ which stimulated the SOD activity, as the time of exposure increased.

The increase in the activity of CAT may be triggered by the generation of $\mathrm{H}_{2} \mathrm{O}_{2}$, while the reduction in the activity of CAT may result in the accumulation of $\mathrm{H}_{2} \mathrm{O}_{2}$. $\mathrm{CAT}$ is known to breakdown hydrogen peroxide which

Table 5 Levels of antioxidant defense systems in earthworms collected from different stations of ljegun $(n=5)$

\begin{tabular}{|c|c|c|c|c|c|c|c|c|c|}
\hline & & & & & & & & & \\
\hline$\overline{\mathrm{GSH}}$ & $28.64 \pm 1.47$ & $0.04 \pm 0.01^{*}$ & $0.1 \pm 0.02^{*}$ & $0.05 \pm 0.02^{*}$ & $0.21 \pm 0.1^{*}$ & $0.02 \pm 0.01^{*}$ & $0.2 \pm 0.2^{*}$ & $0.01 \pm 0^{*}$ & $0.09 \pm 0.1^{*}$ \\
\hline SOD & $235.20 \pm 30.41$ & $0.76 \pm 0.2^{*}$ & $1.94 \pm 0.5^{*}$ & $0.82 \pm 0.3^{*}$ & $2.1 \pm 1.27^{*}$ & $0.34 \pm 0.09$ & $0.69 \pm 0.2^{*}$ & $0.21 \pm 0.1^{*}$ & $0.49 \pm 0.2^{*}$ \\
\hline CAT & $693.00 \pm 78.85$ & $4.61 \pm 1.3^{*}$ & $11.51 \pm 4.2^{*}$ & $5.09 \pm 2.5^{*}$ & $15.91 \pm 6.8^{*}$ & $2.48 \pm 0.55^{*}$ & $11.73 \pm 5.4^{*}$ & $1.5 \pm 0.5^{*}$ & $3.84 \pm 0.6^{*}$ \\
\hline MDA & $2.46 \pm 0.12$ & $1.11 \pm 0.3$ & $1.86 \pm 0.2$ & $1.47 \pm 0.4$ & $2.68 \pm 0.8$ & $9.44 \pm 5.4^{*}$ & $15.45 \pm 0.3^{*}$ & $11.38 \pm 5.5^{*}$ & $17.22 \pm 1.4^{*}$ \\
\hline GST & $395.77 \pm 20.30$ & $0.5 \pm 0.1^{*}$ & $1.47 \pm 0.3^{*}$ & $0.57 \pm 0.3^{*}$ & $2.36 \pm 1.1^{*}$ & $0.36 \pm 0.1^{*}$ & $3.98 \pm 1.9^{*}$ & $0.11 \pm 0.1^{*}$ & $1.28 \pm 0.7^{*}$ \\
\hline
\end{tabular}

CAT Catalase, MDA Malondialdehyde, GSH Total glutathione, GST Glutathione-S- transferase, SOD Superoxide dismutase; statistical significance, treated versus control group:* $(p<0.05)$ 
is a free radical, into water and molecular oxygen. GST is known to be a second stage detoxification enzyme which also helps to remove the products of stage one metabolism (Otitoju and Onwurah 2007; Zhang et al. 2009). Increase in the GST activity was observed for benzene; however, there was decrease in GST activity when the earthworm was exposed to toluene, ethylbenzene, and xylene. This decrease in the activity of GST agrees with the report of Ribera et al. (2001).

BTEX compounds have been known to attach to soil particles; therefore, the hydrocarbon is not available to the earthworm for uptake unlike in water bodies, where they dissolve, becoming water soluble and available for uptake by aquatic organisms. This might be responsible for the changes in the enzymes activities in E. eugeniae after exposure to BTEX compounds observed in this study and previous reports like Song et al. (2009). The significance of using many biological markers to measure the effect of pollutants on organisms has been confirmed (Van der Oost et al. 1997). This study shows that MDA levels were higher in the E. eugeniae after 2 days of exposure to benzene, toluene, ethylbenzene, and xylene. The results from this study are similar to the findings of Saint-Denis et al. (2001), who reported higher levels of MDA in E. fetida after day 14 of exposure to lead. This suggests that ROS has been produced. The increase was followed by a decrease, thereafter, suggesting the elimination of ROS.

Histopathological changes in earthworms have been identified as important markers of toxicity. Kilic (2011) investigated biochemical and histopathological changes of the earthworm (Lumbricus terrestris), and its use as biological marker of pollution in the soil around the Porsuk River Basin in Turkey. The study observed the biomarker changes of Lumbricus terrestris in order to assess the soil pollution along the River Basin. The results showed the biological impacts of pollution in the soil around the Porsuk River Basin in the test organisms, $L$. terrestris and established an early sign of ecosystem alterations compared with the health of humans. The skin of earthworm has straight connection to contaminated soils and is regarded as an important route of ingesting pollutants. Hydrocarbons impact earthworms through access to the skin; this can also occur when earthworms ingest contaminated litter in the soil. These chemicals can get to the coelomic fluid through the skin and can be distributed all over the body of the organisms.

In this study, sub-lethal levels of BTEX compounds induced pathological changes in the body of the earthworms including cellular degeneration, moderate to severe areas of necrosis, areas of inflammation, inclusion bodies, pigments, and distortion of the shapes of circular and longitudinal muscles. Bansiwal and Rai (2010) confirmed this result as they observed marked pathological changes including ruptured cuticle and distortion of shape of muscles after exposure of earthworm to Malathion. Kilic (2011) reported enlargement of epithelial cell lining, necrosis, and loss of structural integrity of circular and longitudinal muscles.

Reactive oxygen species (ROS) produced by the hydrocarbons may be accountable for the various histopathological changes noted in this study. Cellular necrosis can be induced by ROS and inflammation Saint-Denis et al. (2001). Cell swelling and disruption of the plasma membrane are the first stages of necrosis. The core processes of necrosis are bioenergetic failure and rapid loss of plasma membrane integrity. Two types of structural changes can occur as a result of environmental toxicity. The first is where the tissues are affected directly by the toxicant, and this can lead to degeneration and death of the tissue. The second type is when the cells develop compensatory mechanisms like cellular hyperplasia to deal with the toxicant.

\section{Conclusion}

The results obtained in this study have established that the inclusion of the identified biomarkers such as malondialdehyde level, inhibition of SOD, CAT, GST, GSH, and histopathological markers in environmental monitoring programs will ensure early detection of the adverse impacts of petroleum hydrocarbon contamination in the terrestrial environment.

\section{Abbreviations \\ ANOVA: One-way analysis of variance; BSA: Bovine serum albumin; BTEX: Benzene, toluene, xylene, and ethylbenzene; CAT: Catalase; DNA: Deoxyribonucleic acid; GSH: Reduced glutathione; GST: Glutathione S- transferase; KCL: Potassium chloride; LGA: Local government areas; MDA: Malondialdehyde; OECD: Organization for Economic Co-operation and Development; ROS: Reactive oxygen species; SOD: Superoxide dismutase; SPSS: Statistical and Package for Social Science; TOC: Total organic content}

Acknowledgements

There is none.

Availability of data materials

All data generated is already in the manuscript.

Author's contributions

All the authors contributed in writing and in the research study. All authors read and approved the final manuscript.

\section{Authors' information}

I presented this paper as a poster presentation at the 2nd Society of Environmental Toxicology and Chemistry (SETAC AFRICA) conference in Ghana, 7-11 October, 2018.

Funding

Not funded

\section{Ethics approval}

Kindly note that experiments involving invertebrate such as earthworms do not require ethics statement since they are not vertebrates.

Consent for publication

Not applicable. 


\section{Competing interests}

The authors declare that they have no competing interests.

\section{Author details}

${ }^{1}$ Environmental Biology Unit, Department of Biological Science, Yaba College of Technology, Lagos, Nigeria. ${ }^{2}$ Ecotoxicology Unit, Department of Zoology, University of Lagos, Lagos, Nigeria.

\section{Received: 11 March 2019 Accepted: 4 October 2019}

Published online: 09 December 2019

\section{References}

Adewuyi, G. O., \& Olowu, R. A. (2012). Assessment of oil and grease, total petroleum hydrocarbons and some heavy metals in surface and groundwater within the vicinity of NNPC oil depot in Apata, Ibadan metropolis, Nigeria. International Journal of Research and Reviews in Applied Sciences., 13(1), 166-174

Ahmad, I., Pacheco, M., \& Santos, M. A. (2004). Enzymatic and nonenzymatic antioxidants as an adaptation to phagocyte-induced damage in Anguilla anguilla L Following in situ Harbor Water Exposure. Ecotoxicology and Environmental Safety., 57, 290-302.

Akpoborie, I. A., Emoyan, O. O., Asagba, S. O., \& Balogun, A. Y. (2008). Aromatics in private water supplies in Warri, Delta State, Nigeria. Scientia Africa., 1(7), 7480.

An, Y., \& Lee, W. (2008). Comparative and combined toxicities of toluene and methyl tert-butyl to an Asian earthworm, Perionyx excavatus. Chemosphere., 71, 407-411.

ASTDR (2006). Agency for toxic substances and disease registry. Landfill gas primer. An overview for environmental health professionals [Online] [Accessed in June 2005]. Available from URL:http://www.atsdr.cdc.gov/HAC/ landfill/html/ch2.html.

Au, D. W. T. (2004). The application of histo-cytopathological biomarkers in marine pollution monitoring: a review. Marine Pollution Bulletin, 48, 817-834

Avci, A., Kacmaz, M., \& Durak, I. (2005). Peroxidation in muscle and liver tissues from fish in a contaminated river due to a petroleum refinery industry. Ecotoxicology and Environmental Safety, 60, 101-105.

Bansiwal, K. \& Rai, N. (2010). Assessment of malathion toxicity in certain organs of earthworm, Eisenia foetida. An International Quarterly Journal of life sciences. 5(3), 473-476

Budavari, S. (1996). The Merck index: an encyclopedia of chemicals, drugs and biologicals, (12th ed., p. 923). Whitehouse Station: Merck and Co. Inc.

Buege, J. A., \& Aust, S. D. (1978). Microsomal lipid peroxidation. Methods of Enzymology, 52, 302-310.

Daniel-Kalio, L. A., \& Braide, S. A. (2004). The effect of oil spill on a cultivated wetland area of the Niger Delta. Journal of Nigerian Environmental Society. 2(2), 153-158.

De Oliveira, K. M. P. G., Martins, E. M., Arbilla, G., \& Gatti, L. V. (2007). Exposure to volatile organic compounds in an ethanol and gasoline service station. Bulletin of Environmental Contamination and Toxicology, 79, 237-241.

Depledge, M. H. (1996). Genetic ecotoxicology: an overview. Journal of Experimental Marine Biology and Ecology, 200, 57-66.

Doherty, V. F. (2014). Antioxidant enzymes and histopathological biomarkers of exposure to monocyclic aromatic hydrocarbons in Clarias gariepinus (catfish) and Eudrilus eugeniae (earthworm)Ph. D thesis. University of Lagos, (p. 275).

Doherty, V. F., \& Otitoloju, A. A. (2013). Monitoring of soil and groundwater contamination following a pipeline explosion and petroleum product spillage in ljegun, Lagos Nigeria. Environmental Monitoring and Assessment, 185(5), 4159-4170.

Fafioye, O. O., \& Owa, S. O. (2000). Effect of oil contamination on mortality of a eudriline earthworm, Eudrilus eugeniae. Nigerian Journal of Science., 34(4), 355-361.

Farhadian, M., Vachelard, C., Duchez, D., \& Larroche, C. (2008). In situ bioremediation of monoaromatic pollutants in groundwater: A review. Bioresource Technology, 99, 5296-5308.

Fatima, R. A., \& Ahmad, M. (2005). Certain antioxidant enzymes of Allium cepa as biomarkers for the detection of toxic heavy metals in wastewater. The Science of the Total Environment, 346, 256-273.

Guimaraes, C. S., Custodio, D., de Oliveira, R. C. S., Varandas, L. S., \& Arbilla, G. (2010). Comparative study of automative, aircraft and biogenic emissions of aldehydes and aromatic compounds. Bulletin of Environmental Contamination and Toxicology, 84, 180-184.
Habig, W. H., Pabst, M. J., \& Jacoby, W. B. (1974). Glutathione-S-transferases. The first enzymatic step in mercapturic acid formation. Journal of Biological Chemistry, 249, 7130-7139.

labal, J., Gisclair, D., McMillin, D. J., \& Portier, R. J. (2007). Aspects of petrochemical pollution in southeastern Louisiana (USA): pre-Katrina background and source characterization. Environmental Toxicology and Chemistry, 26, 2001-2009.

Kilic, A. K. (2011). Histopathological \& biochemical alterations of earthworm (Lumbricus terrestris) as biomarker of soil pollution along porsuk river basin (Turkey). Chemosphere., 83(8), 1175-1180.

Livingstone, D. R. (2001). Contaminant-stimulated reactive oxygen species production and oxidative damage in aquatic organisms. Marine Pollution Bulletin, 42, 656-666.

Mohamed, S., Kheireddine, O., Wyllia, M. H., \& Roquia, R. (2008). Proportioning of biomarkers (GSH, GST, ache, catalase) indicator of pollution in Gambusia affinis (teleost fish) exposed to cadmium. Environmental Research Journal., 2(4), 177-181.

Motsara, M. R., \& Roy, R. N. (2008). Guide to laboratory establishment for plant nutrient analysis. Rome: FAO Fertilizer and Plant Nutrition Bulletin. Food and Agriculture Organization of the United Nations.

Nganje, T. N., Edet, A. E., \& Ekwere, S. J. (2007). Concentrations of heavy metals and hydrocarbons in groundwater near petrol stations and mechanic workshops in Calabar metropolis, southeastern Nigeria. Environmental Geosciences, 14(1), 1-15.

Nogueira, L., Rodrigues, A. C. F., Tridico, P. C., Fossa, C. E., \& Almeida, E. A. (2010) Oxidative stress in Nile tilapia (Oreochromis niloticus) and armoured catfish (Pterygoplichthys anisitsi) exposed to diesel. Environmental Monitoring and Assessment, 180(1-4), 243-255.

OECD (Organisation for Economic Co-operation and Development) (1984). Guidelines for testing of chemicals No. 207. Earthworm, acute toxicity test. Paris: OECD.

Ogeleka, D. F., Ezemonye, L. I. N., \& Okieimen, F. E. (2010). Toxicity of industrial chemicals on biological indicators in water, sediment and soil. International Research Journal of Biotechnology., 1(3), 037-043.

Olsen, T., Ellerbeck, L., Fisher, T., Callaghan, A., \& Crane, M. (2001). Variability in acetylcholinesterase and glutathione S-transferase activities in Chironomus riparus meigen deployed in situ at uncontaminated field sites. Environmental Toxicology and Chemistry, 20, 1725-1732.

Osu, C. I., \& Asuoha, A. N. (2010). Polycylic aromatic (PAHs) and benzene, toluene, ethylbenzene and xylene (BTEX) contamination of soils in automobile mechanic workshops in Port-Harcourt Metropolis, Rivers State, Nigeria. Journal of American Science, 6(9), 242-246.

Osuji, L. C., \& Achugasim, O. (2010). Trace metals and volatile aromatic hydrocarbon content of Ukpeliede-I oil spillage site, Niger Delta, Nigeria. Journal of Appied Science and Environmental Management., 14(2), 17-20.

Otitoju, O., \& Onwurah, I. N. E. (2007). Glutathione S-transferase (GST) activity as a biomarker in ecological risk assessment of pesticide contaminated environment. African Journal of Biotechnology, 6(12), 1455-1459.

Otitoloju, A. A. (2005). Crude oil plus dispersant: always a boon or bane? Ecotoxicology and Environment al Safety, 60, 198-202.

Padmini, E., Rani, U. M., \& Geetha, V. B. (2009). Studies on antioxidant status in Mugil cephalus in response to heavy metal pollution at Ennore estuary. Environmental Monitoring and Assessment, 155, 215-225.

Ping, L. F., Luo, Y. M., Zhang, H. B., Li, Q. B., \& Wu, L. H. (2007). Distribution of polycyclic aromatic hydrocarbons in thirty typical soil profiles in the Yangtze River Delta region, East China. Environmental Pollution, 147, 358-365.

Renner, K. O., Don-Pedro, K. N., \& Nubi, O. A. (2008). Oil spillage and it's impact on the edible mangrove periwinkle, Tympanotonus fuscatus var radula ( $\mathrm{L})$. Science World Journal., 3(3), 13-16.

Ribera, D., Narbonne, J. F., Arnaud, C., \& Saint-Denis, M. (2001). Biochemical response of earthworms Eisenia fetida andrei exposed to contaminated artificial soil, effects of carbaryl. Soil Biology and Biochemistry, 33, 1123-1130.

Saint-Denis, M., Narbonne, J. F., Arnaud, C., \& Ribeira, D. (2001). Biochemical reponses of the earthworm Eisenia fetida andrei exposed to contaminated artificial soil: effects of lead acetate. Soil Biology and Biochemistry, 33, 395-404.

Saint-Denis, M., Narbonne, J. F., Arnaud, C., Thybaud, E., \& Ribera, D. (1999). Biochemical responses of the earthworm Eisenia fetida exposed to contaminated artificial soil: effects of benzo(a)pyrene. Soil Biology and Biochemistry, 31, 1837-1846.

Sanchez-Hernandez, J. C. (2006). Earthworm biomarkers in ecological risk assessment. Reviews of Environmental Contamination and Toxicoogy., 188, 85-126. 
Schalm, O. W., Jain, N. C., \& Carrol, E. J. (1975). Veterinary haematology, (3rd ed., p. 158). Philadelphia: Leaard Febiger.

Sedlak, J., \& Lindsay, H. R. (1968). Estimation of total protein-bound and nonprotein sulfhydryl groups in tissues with Ellman's reagent. Analytical Biochemistry, 25, 192-205.

Song, Y., Zhu, L. S., Wang, J., Wang, J. H., Liu, W., \& Xie, H. (2009). DNA damage and effects on antioxidative enzymes in earthworm (Eisenia foetida) induced by atrazine. Soil Biology and Biochemistry, 41, 905-909.

Sun, M., \& Zigma, S. (1978). An improved spectrophotometric assay for superoxide dismutase based on epinephrine autoxidation. Analytical Biochemistry, 90(1), 81-89.

Valavanidis, A., Vlahogianni, T., Dassenakis, M., \& Scoullos, M. (2006). Molecular biomarkers of oxidative stress in aquatic organisms in relation to toxic environmental pollutants. Ecotoxicology and Environmental Safety, 64, 178-189.

Van der Oost, R., Vindimian, E., Van der Brink, P. J., Satumalay, K., Heida, H., \& Vermeulen, N. P. E. (1997). Biomonitoring of aquatic pollution with feral eel (Anguilla anguilla) II. Biomarkers: pollution-induced biochemical responses. Aquatic Toxicology, 36(3-4), 189-222.

Wang, G., Mielke, H. W., Quach, V., Gonzales, C., \& Zhang, Q. (2004). Determination of polycyclic aromatic hydrocarbons and trace metals in New Orleans soils and sediments. Soil and Sediment Contamination, 13, 313-327.

Wang, Z., Chen, J., Qiao, X., Yang, P., Tian, F., \& Huang, L. (2007). Distribution and sources of polycyclic aromatic hydrocarbons from urban to rural soils: a case study in Dalian, China. Chemosphere, 68, 965-971.

Xiao, N., Song, Y., \& Ge, F. (2006). Biomarkers responses of the earthworm Eisenia fetida to acetochlor exposure in OECD soil. Chemosphere., 65(6), 907-912.

Ye, B., Zhang, Z., \& Mao, T. (2006). Pollution sources identification of polycyclic aromatic hydrocarbons of soils in Tianjin area, China. Chemosphere, 64, 525-534.

Zhang, J. F., Liu, H., Sun, Y. Y., Wang, X. R., Wu, J. C., \& Xue, Y. Q. (2005). Responses of the antioxidants defenses of the goldfish, Carasisius auratus, exposed to 2,4-dichlorophenol. Environmental Toxicology and Pharmacology, 19, 185-190.

Zhang, X., Lu, Y., Shia, Y., Chen, C., Yang, Z., Li, Y., \& Feng, Y. (2009). Antioxidant and metabolic responses induced by cadmium and pyrene in the earthworm Eisenia fetida in two different systems: contact and soil tests. Chemistry and Ecology, 25(3), 205-215.

Ziech, D., Franco, R., Georgakilas, A. G., Georgakila, S., Malamou-Mitsi, V., Schoneveld, O., \& Panayiotidis, M. I. (2010). The role of reactive oxygen species and oxidative stress in environmental carcinogenesis and biomarker development. Chemico-Biological Interactions, 188(2), 334-339.

Zuo, Q., Duan, Y. H., Yang, Y., Wang, X. J., \& Tao, S. (2007). Source apportionment of polycyclic aromatic hydrocarbons in surface soil in Tianjin, China. Environmental Pollution, 147, 303-310.

\section{Publisher's Note}

Springer Nature remains neutral with regard to jurisdictional claims in published maps and institutional affiliations.

\section{Submit your manuscript to a SpringerOpen ${ }^{\circ}$ journal and benefit from:}

- Convenient online submission

- Rigorous peer review

- Open access: articles freely available online

- High visibility within the field

- Retaining the copyright to your article

Submit your next manuscript at $\boldsymbol{\nabla}$ springeropen.com 